\title{
In Vitro Apatite Deposition on Titania Film Derived from Electrochemical Treatment on Titanium Substrate under Mixed Acid Electrolyte
}

\author{
S S Saleh, H Z Abdullah*, M R Mohamed Yunus
}

Faculty of Mechanical and Manufacturing Engineering, Universiti Tun Hussein Onn Malaysia, Parit Raja 86400, Johor, MALAYSIA.

Received 7 January 2018; accepted 23 January 2018, available online 3 July 2018

\begin{abstract}
Anodic oxidation is used to produce thick titania $\left(\mathrm{TiO}_{2}\right)$ coating layer in a mixture of acids electrolyte to modify the $\mathrm{TiO}_{2}$ which is naturally formed on titanium (Ti) with a thickness of only a few nanometers and inert. The $\mathrm{TiO}_{2}$ coating is then subjected to an in-vitro test to evaluate their bioactivity in simulation body fluid (SBF). In the present work, oxide coatings of $\mathrm{TiO}_{2}$ were formed on $\mathrm{Ti}-\mathrm{Cp}$ foil under potentials of $150 \mathrm{~V}$ at a current density of $100 \mathrm{~mA} / \mathrm{cm}^{2}$ for $10 \mathrm{~min}$. Multiple characterization techniques were used. X-ray diffraction (XRD) is used to obtain mineralogical phase, scanning electron microscope (SEM) is used to obtain surface morphology, water contact angle (WCA) is used to obtain the wettability of the $\mathrm{TiO}_{2}$, and the chemical absorption of the apatite precipitation was tested using Fourier transform infrared spectroscopy (FT-IR). From the testing results, surface morphology obtained an increased porosity with smaller pore size for $\mathrm{TiO}_{2}$, formed in mixed acids with higher molar concentration. Crystalline hydroxyapatite (HA) was obtained on all mixed solution coatings. Higher apatite precipitation and crystalline were obtained on the $\mathrm{TiO}_{2}$ coating with strong $\mathrm{Ti}-\mathrm{O}^{-}$and $\mathrm{Ti}-\mathrm{OH}$ functional groups, porous surface, and strong anatase crystalline.
\end{abstract}

Keywords: Titania, anodic oxidation, crystallization, simulation body fluid, bioactivity

\section{Introduction}

Titanium (Ti) is widely used in dental and orthopedic implants because of its good biocompatibility and high corrosion resistance $[1,2]$. It is believed that these favourable properties are related to oxide layer $\left(\mathrm{TiO}_{2}\right)$ thin film that grows spontaneously upon exposure to air [3]. However, $\mathrm{TiO}_{2}$ is bioinert, which usually leads to insufficient osseointergration $[4,5]$. Therefore, the surface modification of $\mathrm{Ti}$ is required to enhance their bioactivity [6]. $\mathrm{TiO}_{2}$ has shown to exhibit strong physicochemical bonding between Ti implant and living bone because of its ability to induce bone-like apatite in a body environment [7]. $\mathrm{TiO}_{2}$ has three crystalline forms such as anatase, rutile and brookite [8] that may present both in amorphous and crystalline structures, depending on the process parameters. Crystalline oxides, which are anatase and rutile present several distinctive features, such as photocatalytic behaviour $[9,10]$, superhydrophilicity [11] and biocompatible properties [12,13].

To improve Ti bioactivity, several surface-modifying techniques have been applied, such as chemical treatment [14], thermal treatment [15], electrochemical treatment $[16,17]$ and anodisation methods [18,19]. Anodic oxidation is considered one of the most attractive methods for modifying Ti implanted surface [13,20,21]. Anodic oxidation can form porous and relatively firm $\mathrm{TiO}_{2}$ layer on $\mathrm{Ti}$ which is highly beneficial for the biological performance of the implant [22]. Anodic oxidation of $\mathrm{Ti}$ allows the controlled production of protective oxide surface layer much thicker than those formed naturally. These coatings may be dense or porous, amorphous or crystalline, depending on the conditions, such as electrolyte type, solution concentration, and applied potential [23-25]. The electrolytes most commonly used to anodise $\mathrm{Ti}$ are sulphuric acid $\mathrm{H}_{2} \mathrm{SO}_{4}$ and phosphoric acid $\mathrm{H}_{3} \mathrm{PO}_{4}$ [26]. The aqueous electrolytic bath which contains modifying elements in the form of dissolved salts (phosphorous (P) and/or sulfate (S)) need to be incorporated into the resulting $\mathrm{TiO}_{2}$ coating $[27,28]$.

Further improvement of biocompatibility of $\mathrm{Ti}$ for orthopaedic and dental applications is endeavoured through the development of bone-like apatite (hydroxyapatite (HA)) coating on $\mathrm{TiO}_{2}$ interface [29]. It was found that physico-chemical bonding between the metallic implant and living bones could be achieved by the formation of HA in the body environment [30]. HA has frequently been used as coating material on $\mathrm{Ti}$ implants to improve the cell response and osteoconductivity due to its chemical and crystallographic 
similarity to the organic component of the bone $[31,32]$. Several modifying techniques have been proposed to deposit HA on Ti such as plasma spraying [33], sol-gel method [34] and electrochemical deposition [35]. However, the bioactivity of materials can be predicted from the apatite formation in simulated body fluid (SBF), where the existence of phosphorous, calcium, and/or oxygen on anodised sample indicates that HA has grown on that material [23].

$\mathrm{TiO}_{2}$ coating layer formed using anodic oxidation method has proved to induce HA under SBF $[19,36]$. This work evaluates the formation of $\mathrm{HA}$ on $\mathrm{TiO}_{2}$ formed by anodic oxidation. The impact of anodic oxidation parameters on the formation of $\mathrm{HA}$ on $\mathrm{TiO}_{2}$ using SBF will also be studied.

\section{Materials and Methods}

Commercially-pure $\mathrm{Ti}(\mathrm{Cp}-\mathrm{Ti})$ foils of dimensions 25 $\mathrm{mm} \times 10 \mathrm{~mm} \times 0.5 \mathrm{~mm}$ were wet hand-polished using 1200 grit $(\sim 1 \mu \mathrm{m})$ abrasive paper, followed by immersion in ultrasonic bath with acetone, rinsed with distilled water, and dried in air.

Anodic oxidation was performed in electrochemical cell containing $\sim 0.4 \mathrm{~L}$ of diluted mixed aqueous solutions; $\mathrm{H}_{3} \mathrm{PO}_{4}$ (Bendosen, $85 \mathrm{wt} \%$ ) and $\mathrm{H}_{2} \mathrm{SO}_{4}$ (Q-rec, 98 wt \%). The anode and the cathode were both $\mathrm{Ti}$ and the anodising process was performed using a programmable power supply (Gen $750 \mathrm{~W} / 1500 \mathrm{~W}$, TDKLambda). The anodized foils were cleaned using autoclave and stored in distilled water. The associated experimental parameters are shown in Table 1.

Table 1 Parameters used for anodic oxidation in $\mathrm{H}_{2} \mathrm{SO}_{4}$ and $\mathrm{H}_{3} \mathrm{PO}_{4}$ solutions.

\begin{tabular}{lc}
\hline Parameters & Value \\
\hline Room temperature $\left({ }^{\circ} \mathrm{C}\right)$ & 25 \\
\hline & $0.1 \mathrm{M} \mathrm{H}_{2} \mathrm{SO}_{4}$ \\
Electrolyte & $2.0 \mathrm{M} \mathrm{H}_{2} \mathrm{SO}_{4}$ \\
concentration (M) & $0.1 \mathrm{M} \mathrm{H}_{3} \mathrm{PO}_{4}$ \\
& $2.0 \mathrm{M} \mathrm{H}_{3} \mathrm{PO}_{4}$ \\
& $0.1 \mathrm{M} \mathrm{H}_{2} \mathrm{SO}_{4}+0.1 \mathrm{M} \mathrm{H}_{3} \mathrm{PO}_{4}$ \\
& $0.1 \mathrm{M} \mathrm{H}_{2} \mathrm{SO}_{4}+2.0 \mathrm{M} \mathrm{H}_{3} \mathrm{PO}_{4}$ \\
& $2.0 \mathrm{M} \mathrm{H}_{2} \mathrm{SO}_{4}+0.1 \mathrm{M} \mathrm{H}_{3} \mathrm{PO}_{4}$ \\
\hline DC Voltage (V) & 150 \\
\hline Current Density & 100 \\
(mA.cm & \\
\hline Duration (min) & 10 \\
\hline
\end{tabular}

After anodic oxidation process, $\mathrm{TiO}_{2}$ coated samples were subjected to in-vitro test where they were immersed in simulation body fluid $(\mathrm{SBF})(1.5 \mathrm{M})$ at $36.5{ }^{\circ} \mathrm{C}$ in incubator (Incucell MMM Group) for 12 days. SBF were prepared according to Kokubo method [37]. The apatite formation was then evaluated using SEM, XRD, EDX and FT-IR.

The mineralogical phases of the coatings were determined using: (1) X-ray diffraction (XRD,
PANalytical X'Pert ${ }^{3}$ Powder), (2) the surface morphology were examined using scanning electron microscope (SEM, Hitachi SUI510) at accelerating voltage of $15 \mathrm{kV}$, (3) Elemental analyses were done using attached Energy dispersive spectrometer (EDX) (Horiba Emax X-act (®), (4) The hydrophilicity of the $\mathrm{TiO}_{2}$ surface were tested with water contact angle (WCA, Ramé-Hart instrument Co) and (5) the chemical absorption of the apatite precipitation was tested using Fourier transform infrared spectroscopy (FT-IR, Perkin-Elmer Spectrum 100).

\section{Results}

Phase mineralogical analysis of $\mathrm{TiO}_{2}$ coatings produced by individual and mixed acid solutions are shown in Fig. 1 and Fig. 2. Anatase $\left(\mathrm{TiO}_{2}\right.$, JCPDS card \#00-021-1272) and rutile $\left(\mathrm{TiO}_{2}\right.$, JCPDS card \#01-0727374) crystalline were obtained on $\mathrm{TiO}_{2}$ coatings. $\mathrm{TiO}_{2}$ crystalline phases (anatase and rutile) can be observed on $\mathrm{TiO}_{2}$ formed under $\mathrm{H}_{2} \mathrm{SO}_{4}$ solution and mixture solution with higher $\mathrm{H}_{2} \mathrm{SO}_{4}$ concentration (Fig. 1), while $\mathrm{TiO}_{2}$ coatings formed under $\mathrm{H}_{3} \mathrm{PO}_{4}$ solution and mixture solution with higher $\mathrm{H}_{3} \mathrm{PO}_{4}$ concentration have shown amorphous structure (Fig. 2).

According to surface morphology (Fig. 3), generally, the $\mathrm{TiO}_{2}$ surface porosity increased with increased concentration of individual and mixture acids, where the pores have increased in size and number when the molar increased from $0.1 \mathrm{M}$ to $2.0 \mathrm{M}$ at individual and mixed acids. However, the surface morphology and pores size between the coatings are not the same in the case of higher concentration for individual and mixed solutions. In the case of $2.0 \mathrm{M} \mathrm{H}_{2} \mathrm{SO}_{4}$ (Fig. 3(c)) the $\mathrm{TiO}_{2}$ showed flat circular pores with an average diameter of $261.32 \mathrm{~nm}$. Some pores have a circular wall with the donut-like shape. When $0.1 \mathrm{M} \mathrm{H}_{3} \mathrm{PO}_{4}$ is mixed with $2.0 \mathrm{M} \mathrm{H}_{2} \mathrm{SO}_{4}$ (Fig. 3(d)) the surface obtained homogenous sponge-like structure due to the interlacing of pores which lead to increased pore size with an average diameter of 391.84 $\mathrm{nm}$. In the case of $2.0 \mathrm{M} \mathrm{H}_{3} \mathrm{PO}_{4}$ (Fig. 3(f)) the surface morphology is uneven with a different pore size (from 84 $\mathrm{nm}$ to $781 \mathrm{~nm}$ in diameter) and is flat shaped. However, the pore size became homogeneous with smaller volcanoshaped pores having an average diameter of $9.995 \mathrm{~nm}$ when $2.0 \mathrm{M} \mathrm{H}_{3} \mathrm{PO}_{4}$ is mixed with $0.1 \mathrm{M} \mathrm{H}_{2} \mathrm{SO}_{4}$ (Fig. $3(\mathrm{~g}))$. According to in-vitro results under SBF as shown in Fig. 4, the apatite precipitation was appeared on $\mathrm{TiO}_{2}$. It was found that apatite covered all over the floor at low molar solutions for individual and also at mixed solutions, and at mixed solutions with higher $\mathrm{H}_{2} \mathrm{SO}_{4}$ concentration $\left(0.1 \mathrm{H}_{3} \mathrm{PO}_{4}+2.0 \mathrm{H}_{3} \mathrm{PO}_{4}\right)$ (Fig. 4 (a), (b), (d) and (e)). $\mathrm{TiO}_{2}$ anodised at $\left(0.1 \mathrm{H}_{3} \mathrm{PO}_{4}+2.0 \mathrm{H}_{3} \mathrm{PO}_{4}\right)$ has the most condensed apatite after 12 days in SBF.

Hydrophilicity testing is taken after 24 hours of immersion of $\mathrm{TiO}_{2}$ in distilled water, after cleaned using autoclave (Fig. 5). It can be noticed from the results that $\mathrm{TiO}_{2}$ anodised at mixed solutions obtained lower surface contact angle than the coatings anodised in individual solutions, hence higher hydrophilicity. $\mathrm{TiO}_{2}$ coating anodised in $2.0 \mathrm{M} \mathrm{H}_{3} \mathrm{PO}_{4}+0.1 \mathrm{M} \mathrm{H}_{2} \mathrm{SO}_{4}$ has produced the highest hydrophilicity among the other coatings. 
Phase mineralogical analysis spectra as shown in Fig. 6 and Fig. 7 have confirmed the formation of crystalline

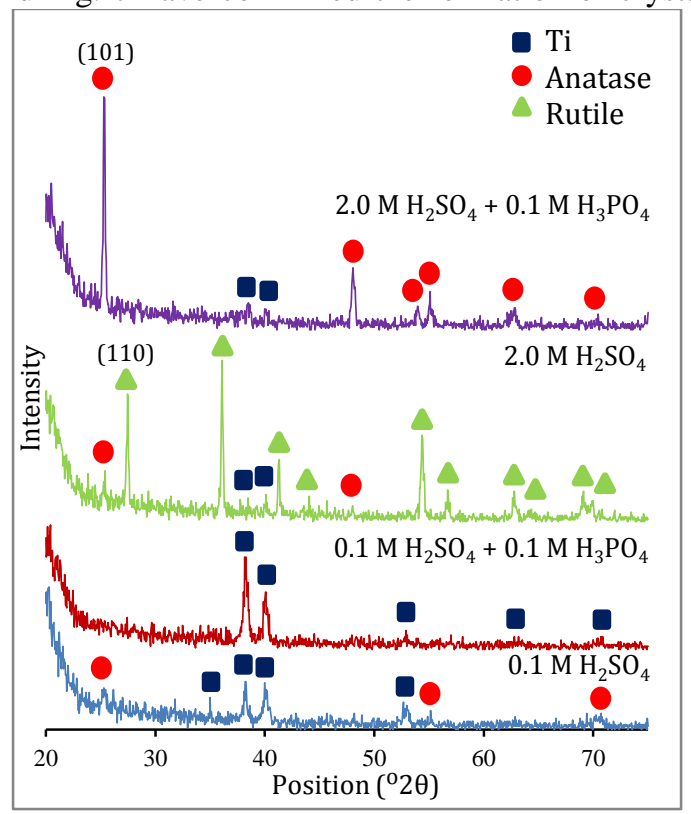

Fig. 1 Phase mineralogical analysis of $\mathrm{TiO}_{2}$ in $0.1 \mathrm{M}$ $\mathrm{H}_{2} \mathrm{SO}_{4}, 2.0 \mathrm{M} \mathrm{H}_{2} \mathrm{SO}_{4}, 0.1 \mathrm{M} \mathrm{H}_{2} \mathrm{SO}_{4}+0.1 \mathrm{M} \mathrm{H}_{3} \mathrm{PO}_{4}$ and $2.0 \mathrm{M} \mathrm{H}_{2} \mathrm{SO}_{4}+0.1 \mathrm{M} \mathrm{H}_{3} \mathrm{PO}_{4}$ at current density 100 $\mathrm{mA} . \mathrm{cm}^{-2}$.

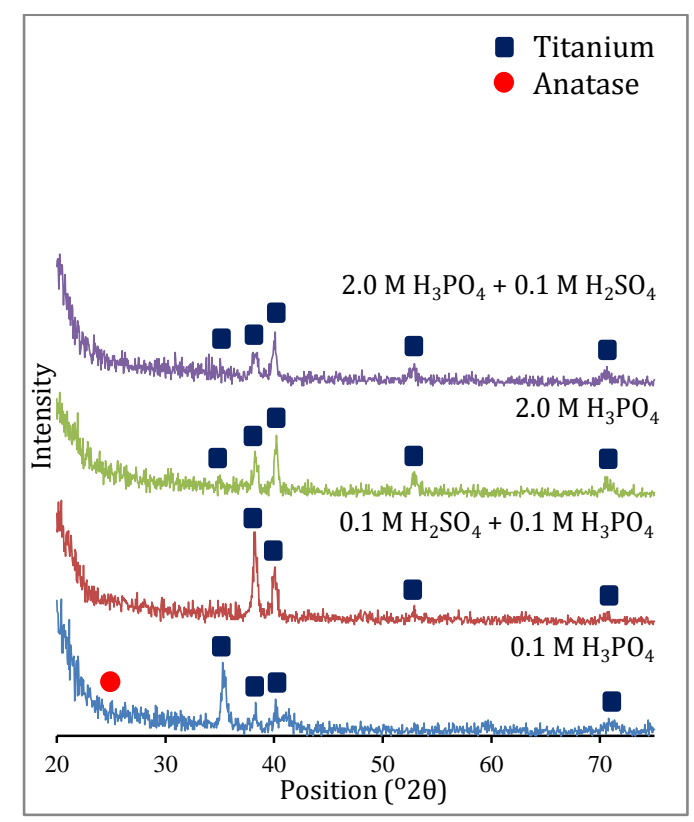

Fig. 2 Phase mineralogical analysis of $\mathrm{TiO}_{2}$ anodised in $0.1 \mathrm{M} \mathrm{H}_{3} \mathrm{PO}_{4}, 2.0 \mathrm{M} \mathrm{H}_{3} \mathrm{PO}_{4}, 0.1 \mathrm{M} \mathrm{H}_{3} \mathrm{PO}_{4}+0.1 \mathrm{M} \mathrm{H}_{2} \mathrm{SO}_{4}$ and $2.0 \mathrm{M} \mathrm{H}_{3} \mathrm{PO}_{4}+0.1 \mathrm{M} \mathrm{H}_{2} \mathrm{SO}_{4}$ at current density 100 $\mathrm{mA} \cdot \mathrm{cm}^{-2}$.

the results from elemental analysis. All precipitations have obtained HA (HA, JCPDS card \#00-055-0592), with exception for $\mathrm{TiO}_{2}$ anodized in $2.0 \mathrm{M} \mathrm{H}_{2} \mathrm{SO}_{4}+0.1 \mathrm{M}$ $\mathrm{H}_{3} \mathrm{PO}_{4}$ which have obtained $\mathrm{HA}$ identified under (HA, JCPDS card \#01-073-6113). It is noticed that low crystalline HA obtained according to peaks with apatite (HA) on all $\mathrm{TiO}_{2}$ coatings surface and agree with

orientations (002) and (211) on $\mathrm{TiO}_{2}$ anodised in higher molar individual solutions $\left(2 \mathrm{M} \mathrm{H}_{2} \mathrm{SO}_{4}\right.$ and $\left.2 \mathrm{M} \mathrm{H}_{3} \mathrm{PO}_{4}\right)$. While coatings anodised on $0.1 \mathrm{M} \mathrm{H}_{2} \mathrm{SO}_{4}$ and $0.1 \mathrm{M}$ $\mathrm{H}_{2} \mathrm{SO}_{4}+\mathrm{H}_{3} \mathrm{PO}_{4}$ obtained the highest crystallinity according to the same peaks.

From absorption spectra for $\mathrm{TiO}_{2}$ as shown in Fig. 8 and Fig. 9 there is a presence of sulfone $(\mathrm{S}=\mathrm{O})$ at band 1300-1350 $\mathrm{cm}^{-1}$ on $\mathrm{TiO}_{2}$ anodised in $\mathrm{H}_{2} \mathrm{SO}_{4}$ solution and phosphine (P-H) at band 950-1200 $\mathrm{cm}^{-1}$ obtained on $\mathrm{TiO}_{2}$ anodised in $\mathrm{H}_{3} \mathrm{PO}_{4}$. Both sulfone and phosphine were obtained on $\mathrm{TiO}_{2}$ anodised in mixed solutions. Hydroxyl groups $(\mathrm{OH})$ stretching region $3100-3400 \mathrm{~cm}^{-1}$ except for $\mathrm{TiO}_{2}$ anodised in $2.0 \mathrm{M} \mathrm{H}_{3} \mathrm{PO}_{4}$ and $\mathrm{Ti}-\mathrm{OH}$ at band 3635 , $3645,3680,3750$ and $3840 \mathrm{~cm}^{-1}$ was also obtained on all the coatings. Water $\left(\mathrm{H}_{2} \mathrm{O}\right)$ at band $1860 \mathrm{~cm}^{-1}$ was also obtained on all the coatings especially in coatings anodised in higher $\mathrm{H}_{2} \mathrm{SO}_{4}$ concentration and in mixed solution with higher $\mathrm{H}_{2} \mathrm{SO}_{4}$, which obtained stronger water absorption band. This is due to the water trapped inside the grooves on their complicated porous structure (Fig. 3).

\section{Discussion}

It is apparent that the high apatite formation has obtained higher HA crystalline peaks. Higher apatite was obtained higher on the $\mathrm{TiO}_{2}$ coatings anodised in lower molar concentration for an individual solution and at mixed solutions with level and higher $\mathrm{H}_{2} \mathrm{SO}_{4}$ concentration. The $\mathrm{TiO}_{2}$ anodised at lower molarity has obtained lower porosity, thus smoother surface, however, higher apatite was also formed on the higher porous surface $\left(0.1 \mathrm{M} \mathrm{H}_{3} \mathrm{PO}_{4}+2.0 \mathrm{M} \mathrm{H}_{2} \mathrm{SO}_{4}\right)$. The higher wettability of the $\mathrm{TiO}_{2}$ coating anodised in mixed solution can be related the incorporation of $\mathrm{S}$ and $\mathrm{P}$ ions within the solution, however, this hypothesis needs further study. The hydrophilicity has obtained the highest on the $\mathrm{TiO}_{2}$ coating anodised in $0.1 \mathrm{M} \mathrm{H}_{3} \mathrm{PO}_{4}+2.0 \mathrm{M} \mathrm{H}_{2} \mathrm{SO}_{4}$. This is can be due to the hydroxylated surface [38] as obtained in the strong Ti-OH stretch around (around $1050 \mathrm{~cm}^{-1}$ ). The $\mathrm{TiO}_{2}$ coating anodised in $0.1 \mathrm{M}$, however, didn't obtain hydrophilicity surface, although the increased apatite precipitation. The increased apatite formation can be attributed to the strong Ti-O $\mathrm{O}^{-}$stretch around $600 \mathrm{~cm}^{-1}$ at $0.1 \mathrm{M} \mathrm{H}_{2} \mathrm{SO}_{4}, 0.1 \mathrm{M} \mathrm{H}_{3} \mathrm{PO}_{4}$ and $0.1 \mathrm{M} \mathrm{H}_{3} \mathrm{PO}_{4}+0.1 \mathrm{M}$ $\mathrm{H}_{2} \mathrm{SO}_{4}$. The higher apatite formed on the $\mathrm{TiO}_{2}$ coating 0.1 $\mathrm{M} \mathrm{H}_{3} \mathrm{PO}_{4}+2.0 \mathrm{M} \mathrm{H}_{2} \mathrm{SO}_{4}$ can be related to the Ti-OH (hydroxylated) groups, thus higher hydrophilicity, Ti-O functional groups, porous surface and strong anatase crystalline. It has been reported that osseointegration is better led by higher surface roughness, higher wettability and increased number and size of micro-pores $[39,40]$. It is also reported that the $\mathrm{Ti}-\mathrm{OH}$ groups on $\mathrm{TiO}_{2}$ provide active sites for apatite nucleation when arranged in a specific structural unit based on the anatase structure, have been proposed to be responsible for the apatite formation [41]. It has also been reported that anatase present low contact angle [39]. 
International Journal of Integrated Engineering: Special Issue 2018: Seminar on

Postgraduate Study, Vol. 10 No. 3 (2018) p. 102-108

(c) Penerbit UTHM

DOI: https://doi.org/10.30880/ijie.xx.xx.xxxx.xx.xxxx
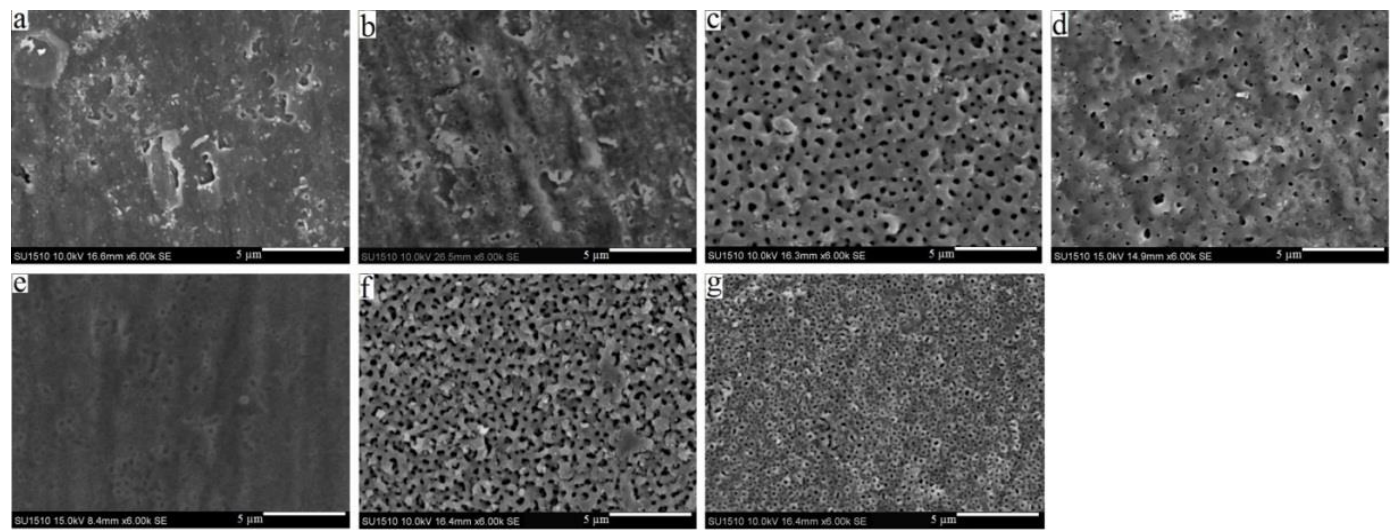

Fig. 3 Surface morphology of $\mathrm{TiO}_{2}$ film surfaces obtained as follows: (a) $0.1 \mathrm{M} \mathrm{H}_{2} \mathrm{SO}_{4}$, (b) $0.1 \mathrm{M} \mathrm{H}_{3} \mathrm{PO}_{4}$, (c) $2.0 \mathrm{M}$ $\mathrm{H}_{2} \mathrm{SO}_{4}$, (d) $2.0 \mathrm{M} \mathrm{H}_{3} \mathrm{PO}_{4}$, (e) $0.1 \mathrm{M} \mathrm{H}_{2} \mathrm{SO}_{4}+0.1 \mathrm{M} \mathrm{H}_{3} \mathrm{PO}_{4}$, (f) $2.0 \mathrm{M} \mathrm{H}_{2} \mathrm{SO}_{4}+0.1 \mathrm{M} \mathrm{H}_{3} \mathrm{PO}_{4}$ (g) $2.0 \mathrm{M} \mathrm{H}_{3} \mathrm{PO}_{4}+0.1 \mathrm{M}$ $\mathrm{H}_{2} \mathrm{SO}_{4}$ at current density $100 \mathrm{~mA} . \mathrm{cm}^{-2}$.
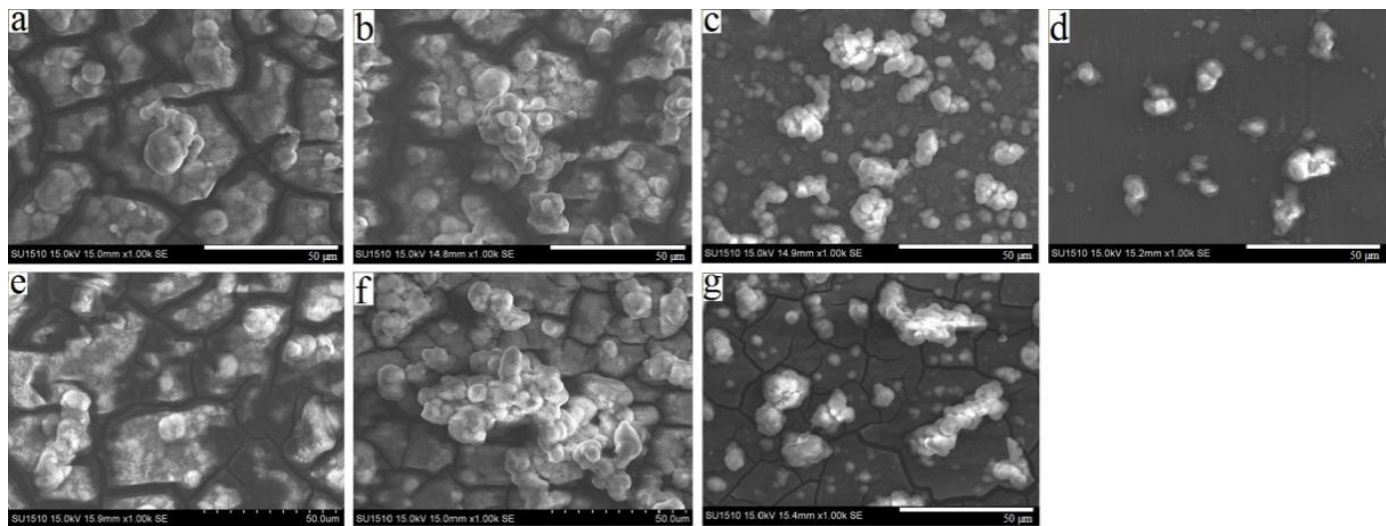

Fig. 4 Surface morphology of $\mathrm{TiO}_{2}$ surfaces immersed for 12 days in $\mathrm{SBF}$ obtained as follows: (a) $0.1 \mathrm{M} \mathrm{H}_{2} \mathrm{SO}_{4}$, (b) 0.1 $\mathrm{M} \mathrm{H}_{3} \mathrm{PO}_{4}$, (c) $2.0 \mathrm{M} \mathrm{H}_{2} \mathrm{SO}_{4}$, (d) $2.0 \mathrm{M} \mathrm{H}_{3} \mathrm{PO}_{4}$, (e) $0.1 \mathrm{M} \mathrm{H}_{2} \mathrm{SO}_{4}+0.1 \mathrm{M} \mathrm{H}_{3} \mathrm{PO}_{4}$, (f) $2.0 \mathrm{M} \mathrm{H}_{2} \mathrm{SO}_{4}+0.1 \mathrm{M} \mathrm{H}_{3} \mathrm{PO}_{4}$ (g) 2.0 $\mathrm{M} \mathrm{H}_{3} \mathrm{PO}_{4}+0.1 \mathrm{M} \mathrm{H}_{2} \mathrm{SO}_{4}$ at current density $100 \mathrm{~mA} \cdot \mathrm{cm}^{-2}$.

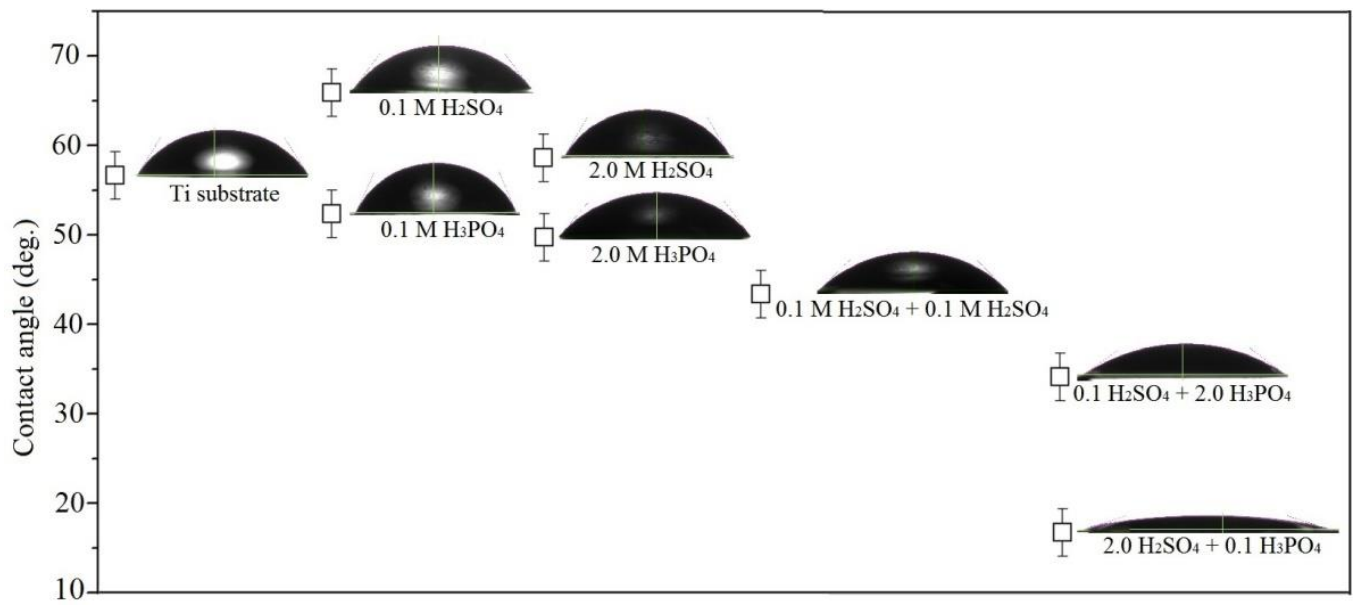

Fig. 5 Surface energy analysis on $\mathrm{TiO}_{2}$ surface

\section{Conclusion}

Higher apatite precipitation and crystalline were obtained on the $\mathrm{TiO}_{2}$ coating with strong $\mathrm{Ti}^{-} \mathrm{O}^{-}$functional groups for individual and mixed solutions. Higher apatite was obtained on hydroxylated $\mathrm{TiO}_{2}$ coating that has obtained strong Ti-OH functional groups, also highly porous surface and strong anatase crystalline. 


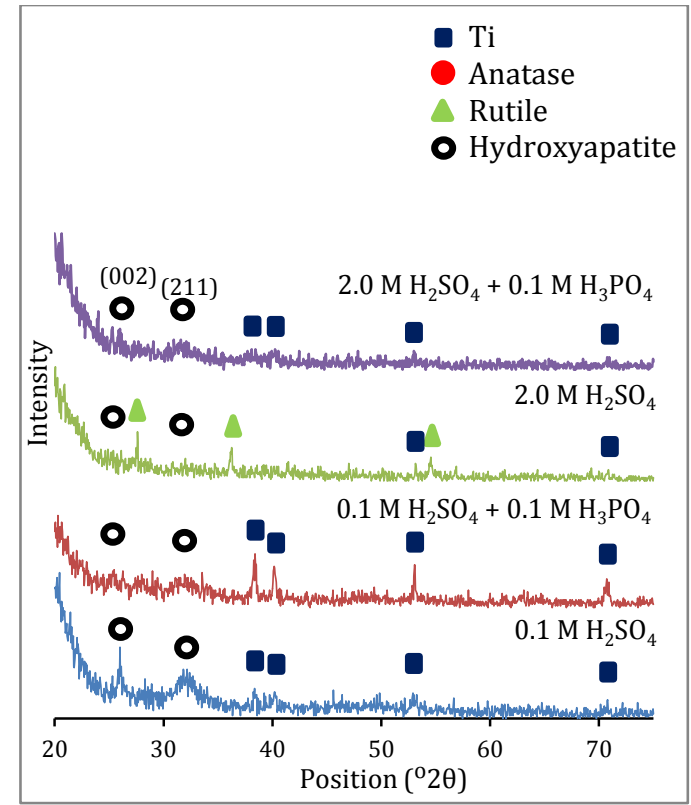

Fig. 6 Phase mineralogical analysis of $\mathrm{TiO}_{2}$ surfaces immersed for 12 days in SBF anodized films obtained in $0.1 \mathrm{M} \mathrm{H}_{2} \mathrm{SO}_{4}, 2.0 \mathrm{M} \mathrm{H}_{2} \mathrm{SO}_{4}, 0.1 \mathrm{M} \mathrm{H}_{2} \mathrm{SO}_{4}+0.1 \mathrm{M} \mathrm{H}_{3} \mathrm{PO}_{4}$ and 2.0 $\mathrm{M} \mathrm{H}_{2} \mathrm{SO}_{4}+0.1 \mathrm{M} \mathrm{H}_{3} \mathrm{PO}_{4}$.

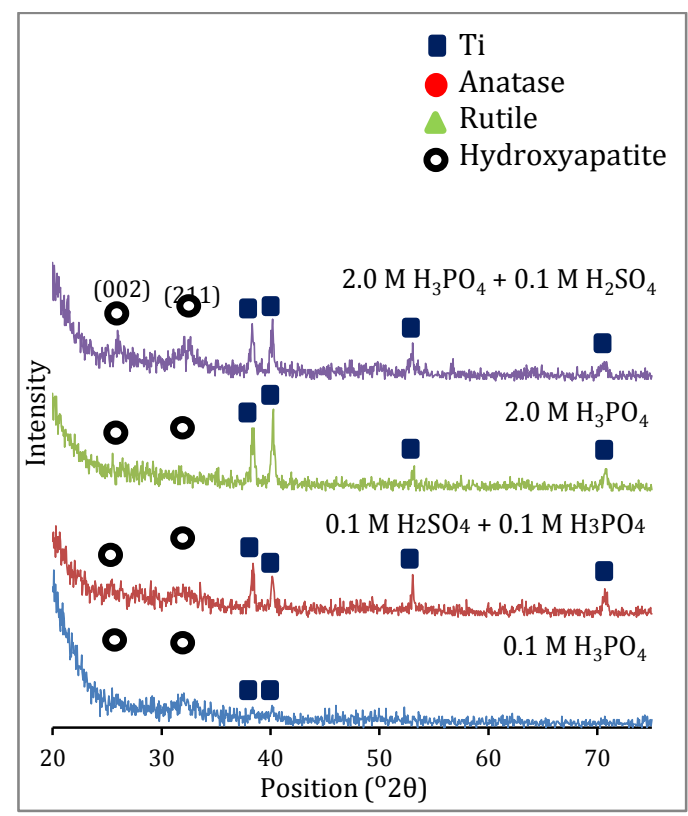

Fig. 7 Phase mineralogical analysis of $\mathrm{TiO}_{2}$ surfaces immersed for 12 days in SBF anodized films obtained in $0.1 \mathrm{M} \mathrm{H}_{3} \mathrm{PO}_{4}, 2.0 \mathrm{M} \mathrm{H}_{3} \mathrm{PO}_{4}, 0.1 \mathrm{M} \mathrm{H}_{3} \mathrm{PO}_{4}+0.1 \mathrm{M} \mathrm{H}_{2} \mathrm{SO}_{4}$ and 2.0 $\mathrm{M} \mathrm{H}_{3} \mathrm{PO}_{4}+0.1 \mathrm{M} \mathrm{H}_{2} \mathrm{SO}_{4}$.

\section{Acknowledgment}

The authors gratefully acknowledge Ministry of Higher Education, Malaysia for the financial support provided for the research through Research Grant Scheme; FRGS vot 1212. This paper was also partly sponsored by Centre for Graduate Studies, UTHM.

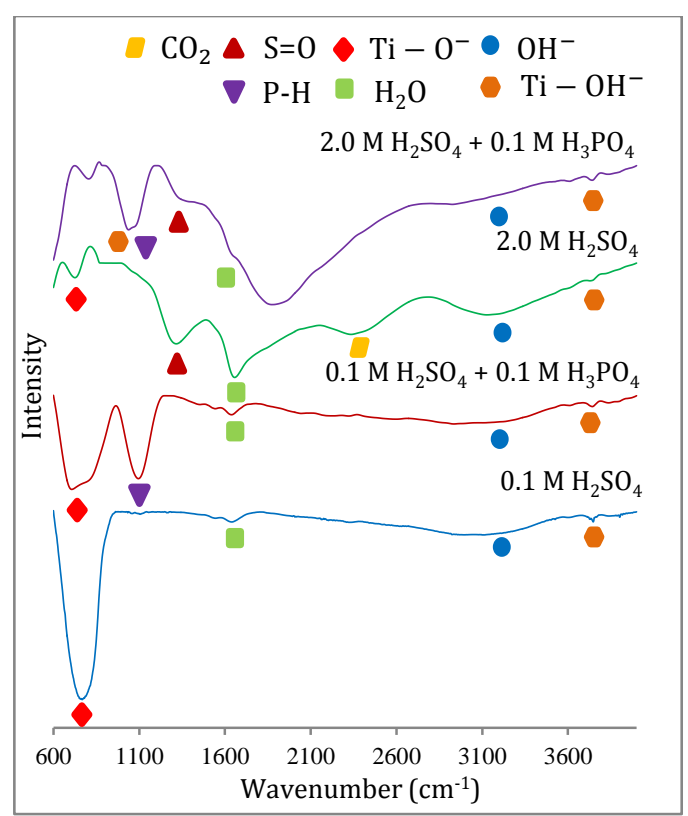

Fig. 8 Absorption analysis of $\mathrm{TiO}_{2}$ surfaces obtained in $0.1 \mathrm{M} \mathrm{H}_{3} \mathrm{PO}_{4}, 2.0 \mathrm{M} \mathrm{H}_{3} \mathrm{PO}_{4}, 0.1 \mathrm{M} \mathrm{H}_{3} \mathrm{PO}_{4}+0.1 \mathrm{M} \mathrm{H}_{2} \mathrm{SO}_{4}$ and $2.0 \mathrm{M} \mathrm{H}_{3} \mathrm{PO}_{4}+0.1 \mathrm{M} \mathrm{H}_{2} \mathrm{SO}_{4}$.

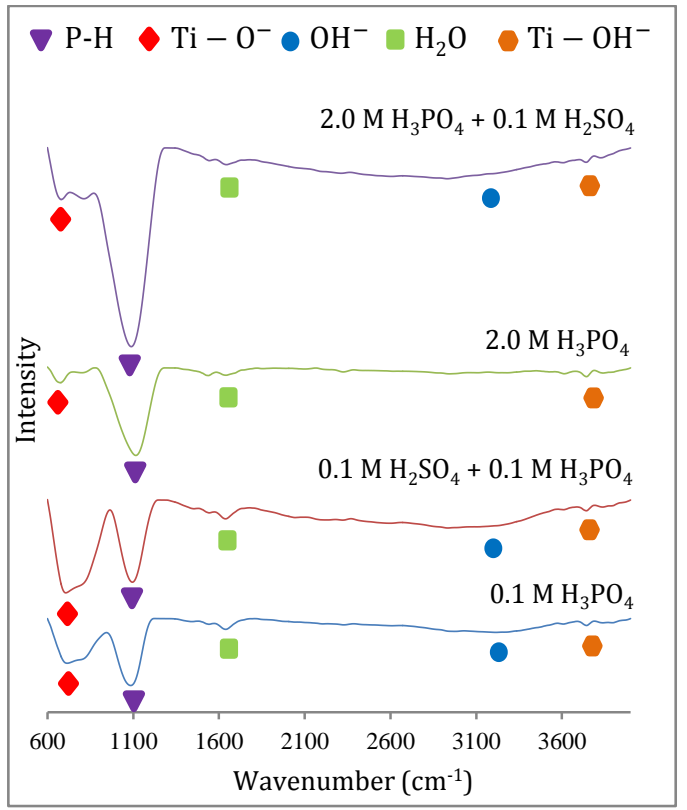

Fig. 9 Absorption analysis of $\mathrm{TiO}_{2}$ surfaces obtained in $0.1 \mathrm{M} \mathrm{H}_{3} \mathrm{PO}_{4}, 2.0 \mathrm{M} \mathrm{H}_{3} \mathrm{PO}_{4}, 0.1 \mathrm{M} \mathrm{H}_{3} \mathrm{PO}_{4}+0.1 \mathrm{M} \mathrm{H}_{2} \mathrm{SO}_{4}$ and $2.0 \mathrm{M} \mathrm{H}_{3} \mathrm{PO}_{4}+0.1 \mathrm{M} \mathrm{H}_{2} \mathrm{SO}_{4}$.

\section{References}

[1] Adell, R., Eriksson, B., Lekholm, U., Brånemark, P.I., and Jemt, T. Long-term follow-up study of osseointegrated implants in the treatment of totally edentulous jaws. The International Journal of Oral and Maxillofacial Implants, Volume 5, (1990), pp. 347-359.

[2] van Steenberghe, D., Lekholm, U., Bolender, C., Folmer, T., Henry, P., Herrmann, I., and Astrand, P. 
Applicability of osseointegrated oral implants in the rehabilitation of partial edentulism: a prospective multicenter study on 558 fixtures. The International Journal of Oral and Maxillofacial Implants, Volume 5, (1990), pp. 272-281.

[3] Sul, Y.T., Johansson, C.B., Petronis, S., Krozer, A., Jeong, Y., Wennerberg, A., and Albrektsson, T. Characteristics of the surface oxides on turned and electrochemically oxidized pure titanium implants up to dielectric breakdown: the oxide thickness, micropore configurations, surface roughness, crystal structure and chemical composition. Biomaterials, Volume 23, (2002), pp. 491-501.

[4] Fathi, M.H., Salehi, M., Saatchi, A., Mortazavi, V., and Moosavi, S.B. Novel double layer hydroxyapatite (HA)/Ti coating for biocompatibility improvement of metallic implants. Surface Engineering, Volume 17, (2001).

[5] Xiao, F., Tsuru, K., Hayakawa, S., and Osaka, A. In vitro apatite deposition on titania film derived from chemical treatment of $\mathrm{Ti}$ substrates with an oxysulfate solution containing hydrogen peroxide at low temperature. Thin Solid Films, Volume 441, (2003), pp. 271-276.

[6] Li, B., Li, J., Liang, C., Li, H., Guo, L., Liu, S., and Wang, H Surface Roughness and Hydrophilicity of Titanium after Anodic Oxidation. Rare Metal Materials and Engineering, Volume 45, (2016), pp. 858-862.

[7] Hazan, R., Brener, R and Oron, U. Bone growth to metal implants is regulated by their surface chemical properties. Biomaterials, Volume 14, (1993), pp. 570-574.

[8] Dikici, T., Erol, M., Toparli, M., and Celik, E. Characterization and photocatalytic properties of nanoporous titanium dioxide layer fabricated on pure titanium substrates by the anodic oxidation process. Ceramics International, Volume 40, (2014), pp. 1587-1591.

[9] Taib, S.S., Ahmad, M.K., Abdul Rahman, M. Z., Mohamad, F., Nafarizah, N., Soon, C.F., Ameruddin, A.B., Shimomura, M., and Murakami, $\mathrm{K}$. $\mathrm{TiO}_{2}$ based dye-sensitized solar cell prepared by spray pyrolysis deposition (spd) technique. International Journal of Integrated Engineering, Volume 10, (2018), pp. 109-113.

[10] Shen, L., Bao, N., Zheng, Y., Gupta, A., An, T., and Yanagisawa, K. Hydrothermal splitting of titanate fibers to single-crystalline $\mathrm{TiO}_{2}$ nanostructures with controllable crystalline phase, morphology, microstructure, and photocatalytic activity. Journal of Physical Chemistry C, Volume 112, (2008), pp. 8809-8818.

[11] Liu, G., Du, K., and Wang, K. Surface wettability of $\mathrm{TiO}_{2}$ nanotube arrays prepared by electrochemical anodization. Applied Surface Science, Volume 388, (2016), pp. 313-320.

[12] Kokubo, T. Apatite formation on surfaces of ceramics, metals and polymers in body environment. Acta Materialia, Volume 46, (1998), pp. 2519-2527.

[13] Park, K.H., Heo, S.J., Koak, J.Y., Kim, S.K., Lee, J.B., Kim, S.H., and Lim, Y.J. Osseointegration of anodized titanium implants under different current voltages: A rabbit study. Journal of Oral Rehabilitation, Volume 34, (2007a), pp. 517-527.

[14] Senain, I., Nayan, N and Saim, H. Structural and Electrical Properties of $\mathrm{TiO}_{2}$ Thin Film Derived from Sol-gel Method using Titanium (IV) Butoxide. International Journal of Integrated Engineering (Issue on Electrical and Electronic Engineering), (2013), pp. 29-35.

[15] Wei, D., Zhou, Y., Jia, D., and Wang, Y. Effect of heat treatment on the structure and in vitro bioactivity of micro arc-oxidized (MAO) titania coatings containing $\mathrm{Ca}$ and $\mathrm{P}$ ions. Surface and Coatings Technology, Volume 201, (2007), pp. 8723-8729.

[16] Lee, K., Ko, Y.-M., Choe, H.-C., and Kim, B.-H. Formation of nano-phase hydroxyapatite film on $\mathrm{TiO}_{2}$ nano-network. Journal of Nanoscience and Nanotechnology, Volume 12, (2012), pp. 822-827.

[17] Sul, Y.T., Johansson, C.B., Jeong, Y., and Albrektsson, T. The electrochemical oxide growth behavior on titanium in acid and alkaline electrolytes. Medical Engineering and Physics, Volume 23, (2001), pp. 329-346.

[18] Wang, Y., Yu, H., Chen, C., and Zhao, Z. Review of the biocompatibility of micro-arc oxidation coated titanium alloys. Materials and Design, Volume 85, (2015), pp. 640-652.

[19] Yang, B., Uchida, M., Kim, H.-M., Zhang, X and Kokubo, T. Preparation of bioactive titanium metal via anodic oxidation treatment. Biomaterials, Volume 25, (2004), 1003-1010.

[20] Han, Y and Xu, K. Photoexcited formation of bone apatite-like coatings on micro-arc oxidized titanium. Journal of Biomedical Materials Research-Part A, Volume 71, (2004), pp. 608-614.

[21] Park, Y.-J., Shin, K.-H., and Song, H.-J. Effects of anodizing conditions on bond strength of anodically oxidized film to titanium substrate. Applied Surface Science, Volume 253, (2007b), pp. 6013-6018.

[22] Lee, K., Jeong, Y.-H., Brantley, W. A., and Choe, H.-C. Surface characteristics of hydroxyapatite films deposited on anodized titanium by an electrochemical method. Thin Solid Films, Volume 546, (2013), pp. 185-188.

[23] Abdullah, H.Z., and Sorrell, C.C. $\mathrm{TiO}_{2}$ thick films by anodic oxidation. Journal of the Australian Ceramic Society, Volume 43, (2007), pp. 125.

[24] Jaeggi, C., Kern, P., Michler, J., Zehnder, T., and Siegenthaler, H. Anodic thin films on titanium used as masks for surface micropatterning of biomedical devices. Surface and Coatings Technology, Volume 200, (2005), pp. 1913-1919.

[25] Saleh, S.S., and Abdullah, H.Z. Optimization and characterization of anatase formed on anodized titanium in mixed acids. ARPN Journal of Engineering and Applied Sciences, Volume 11, 
(2016), pp. 9809-9814.

[26] Diamanti, M.V., and Pedeferri, M.P. Effect of anodic oxidation parameters on the titanium oxides formation. Corrosion Science, Volume 49, (2007), pp. 939-948.

[27] Song, W.-H., Jun, Y.-K., Han, Y., and Hong, S.-H. Biomimetic apatite coatings on micro-arc oxidized titania. Biomaterials, Volume 25, (2004), pp. 33413349.

[28] Sul, Y. T. The significance of the surface properties of oxidized titanium to the bone response: Special emphasis on potential biochemical bonding of oxidized titanium implant. Biomaterials, Volume 24, (2003), pp. 3893-3907.

[29] Hayashi, K., Matsuguchi, N., Uenoyama, K., Kanemaru, T., and Sugioka, Y. Evaluation of metal implants coated with several types of ceramics as biomaterials. Journal of Biomedical Materials Research, Volume 23, (1989), pp. 1247-1259.

[30] Milella, E., Cosentino, F., Licciulli, A., and Massaro, C. Preparation and characterisation of titania/hydroxyapatite composite coatings obtained by sol-gel process. Biomaterials, Volume 22, (2001), pp. 1425-1431.

[31] Hench, L.L. Bioceramics. Journal of the American Ceramic Society, Volume 81, (1998), pp. 17051728.

[32] Lee, K., Choe, H.-C., Kim, B.-H., and Ko, Y.-M. The biocompatibility of HA thin films deposition on anodized titanium alloys. Surface and Coatings Technology, volume 205, (2010), pp. S267-S270.

[33] Zheng, X., Huang, M., and Ding, C. Bond strength of plasma-sprayed hydroxyapatite/Ti composite coatings. Biomaterials, Volume 21, (2000), pp. 841849.

[34] Hsieh, M.-F., Perng, L.-H., and Chin, T.-S. Hydroxyapatite coating on Ti6Al4V alloy using a sol-gel derived precursor. Materials Chemistry and Physics, Volume 74, (2002), pp. 245-250.

[35] Zhang, Q., Leng, Y., and Xin, R. A comparative study of electrochemical deposition and biomimetic deposition of calcium phosphate on porous titanium. Biomaterials, Volume 26, (2005), pp. 2857-2865.

[36] Kim, H. M., Kaneko, H., Kawashita, M., and Kokubo, T., and Nakamura, T. Mechanism of Apatite Formation on Anodically Oxidized Titanium Metal in Simulated Body Fluid. Key Engineering Materials, Volume 254-256, (2004), pp. 741-744.

[37] Kokubo, T., and Takadama, H. How useful is SBF in predicting in vivo bone bioactivity?. Biomaterials, Volume 27, (2006), pp. 2907-2915.

[38] Yu, J., Zhao, X., Zhao, Q., and Wang, G. Preparation and characterization of superhydrophilic porous $\mathrm{TiO}_{2}$ coating films. Materials Chemistry and Physics, Volume 68, (2001), pp. 253259.

[39] Das, K., Bose, S and Bandyopadhyay, A. Surface modifications and cell-materials interactions with anodized Ti. Acta Biomaterialia, Volume 3, (2007), pp. 573-585.
[40] Zhu, X., Chen, J., Scheideler, L., Reichl, R., and Geis-gerstorfer, J. Effects of topography and composition of titanium surface oxides on osteoblast responses. Biomaterials, Volume 25, (2004), pp. 4087-4103.

[41] Uchida, M., Kim, H.-M., Kokubo, T., and Nakamura, T. Apatite-Forming Ability of SodiumContaining Titania Gels in a Simulated Body Fluid. Journal of the American Ceramic Society, Volume 84, (2001), pp. 2969-2974. 